\title{
ENHANCING STUDENTS' TRANSLATION ABILITY THROUGH GROUP WORK
}

\author{
Rulik Setiani ${ }^{1}$ \\ rulik.setiani@yahoo.com
}

\section{Universitas Muhammadiyah Kotabumi}

\begin{abstract}
Translation is a compulsory subject which must be mastered by the sixth semester students of STKIP Muhammadiyah Kotabumi, by mastering this course, they automatically also must master the mastery of English vocabulary and grammar. One of the ways done by lecturer in improving the ability to translate Indonesian into English and vice versa by the application of group work technique. The aim of this article is to describe the application of group work technique in teaching students' translation. There are some steps done in learning process as follows: the lecturer needs to prepare a syllabus, semester learning plan, teaching materials, and also the media used by lecturer in the learning process of translation courses. The first step taken by the lecturer in this case is Plan, while in the main activity through group work technique, the lecturer asks students to make groups of 3 to 4 students to translate the text given by the lecturer, when they are finished, the lecturer checks the results of the group by submitting the answers or also discussed together, other ways of group work is in pairs. The lecturer also gives appreciation to each group that can answer correctly; at this stage the lecturer also observes the learning process of students. The last stage is reflection, at this stage the lecturer presents the findings during the learning process, this aims to improve the learning process in the next stage is better and increased.
\end{abstract}

Keywords: Enhanching, Translation, Ability, Group Work

Abstrak: Translation merupakan mata kuliah wajib yang harus dikuasi oleh mahasiswa semester VI STKIP Muhammadiyah Kotabumi, dengan menguasai mata kuliah ini, otomatis mereka juga harus menguasai penguasaan kosa kata dan tata bahasa bahasa Inggris. Tujuan dari penulisan artikel ini yaitu untuk mendeskripsikan aplikasi penggunaan tehnik kerja kelompok (Group Work) dalam meningkatkan pembelajaran menerjemahkan. Ada beberapa langkah yang dilakukan oleh dosen dalam meningkatkan kemampuan menerjemahkan bahasa Indonesia kedalam bahasa Inggris dan sebaliknya langkah-langkah tersebut diantaranya sebelum pembelajaran dimulai dosen perlu menyiapkan silabus, rencana pembelajaran semester (RPS), bahan ajar, dan juga media yang digunakan dosen dalam proses pembelajaran mata kuliah Translation. Langkah yang pertama dilakukan oleh dosen dalam hal tersebut yaitu Plan, sedangkan pada tahap do melalui tehnik kerja kelompok dosen meminta mahasiswa untuk membentuk kelompok beranggotakan 3 sampai 4 untuk menerjemahkan teks yang diberikan dosen, jika mereka sudah selesai dosen mengecek hasil kerja kelompoknya dengan cara menyampaikan jawabanya ataupun juga dengan dibahas bersama-sama, bentuk kerja yanglainya yaitu dengan berpasangan (in pairs). Dosen juga memberi apresiasi pada setiap kelompok yang dapat menjawab dengan benar, pada tahap ini dosen juga mengamati proses pembelajaran mahasiswa. Tahap yang terahir yaitu see, pada tahap ini dosen menyampaikan temuan-temuan selama proses pembelajaran, ini bertujuan untuk perbaikan agar proses pembelajaran pada tahap berikutnya lebih baik dan meningkat.

Kata Kunci: Meningkatkan, Kemampuan, Menterjemahkan, Group Work 


\section{INTRODUCTION}

Translation is the rendering or renewal of representation of a source language (L1) by representing of another languageor source language (L2). Translating is related with a written language. According to Mc.Arthur in Rokhman (2008:9), translation is an effort to explain an idea from one language to others. This word the same with translation in English come from Latin language that is "translatio or translationis" which means "what is carried across." Translating is different with interpreting. Translating is relates with the written language and interpreting is effort to translate orally.In translating there are two languages namely, source language (SL) and target or receptor Language (TL). Source language or origin language is a text or language that is translated and target language is the result of translation. Source language or receptor language (SL) and target or receptor language (TL) have the different role. It is also an essential thing that should be able by students for the sake of achieving a sucessful learning process.

The lecturer has to play an important role in teaching and learning. The lecturer should select good strategies, techniques for particular purposes. The selection of the strategy and also technique should depend on the students need. For the reason, group work technique can be employed. This technique is meant to avoid a conventional technique that has not been interesting. In group work, the teacher asks the students to make several groups. By applying this technique, the students can discuss and share each others with their friends relates the material discussed. According to Tuchman in Slavin (2005:125), students who those applied by this technique of group work have good change of learning and they are able to perform well than they who those not this technique. It is a good way to let them to work together in small groups of four or five because it is possible for them to have a good exchange of information and discussion and a lot of peer help. The better students can help the slower students.

Cooperative learning in group work technique serves studentsthe opportunityin getting their understanding and abilityduringdiscussion with their teams. It is alsoappropriateto develop or increase social interaction and language skills. It is also the students should be able to share each other the information relate the material discussed during learning and able to overcome their learning together. According to Douglas in Febrina and Zaim(2013:2), group work is able toincreaseall students bysharing and interacting with their members in their group or other groups. It means that by this way it can increase and buildgood and warm atmospheres in the class during learning 
process. The appropriate of using group work technique in teaching language classroom gives somebenefits for the students. The first, this wayreveals the ability of students to share, discuss, and overcome their material with anothermembers in their group. The second, this way is not wasting a time and it is very effective to do and discuss their works. The third, itallows and give opportunity for small sections or units to be finished their project as a whole. In conclusion, group work is able tobuild students' practice, the quality of their works, their motivation, and eagerduring teaching and learning process.

\section{THEORY REVIEW}

\subsection{Translation Ability}

Translation is communicative meaningful device in contexts where the English user called with a translator. It is also a well-proven communication strategy for students of a second language.According to Bell (1991:5), translation is the expression in other languages, target language, or receptor language. It is also rendering/transferring material or text in another language.Similarly, Catford in Nababan (1999:19) said that Translation is the renewal and re-express of textual material in a language or origin language by equivalent textual material in receptor languages. In translating of the text is pressured so that the message of source language is similar with the message of target language.

Similarly, Larson in Djuharie (2004:12) statedthat Translation is studying the lexical and grammatical structure the original language or source language by analyzing to complete its meaning, then it is reorganizing the same meaning using the appropriate lexical and grammatical structure which in the form of receptor language or target language.

Definition of translation can be categorized into three kinds namely, intralingual, interlingual, and intersemiotic translation. The first term indicates of effort to express an idea or thought in similar language. It is called in english as paraphrase. The second term is translating of thought or idea from one language to another language. Then, the last term is translating of thought or idea from verbal to non-verbal language (Jakobson in Rokhman, 2008:9).

Crystal in Rokhman (2008:10) also says that there are three stages of translation which have each different stressing: wordfor-word, literal, and free translation. First stage is called word-for-word. This translation model which tries to translate the text from source language to target language or receptor language by looking for their grammatical similarity. The second stage is literal translation. In this stage, the translation is focus on literal meaning of 
words, phrases, clauses, and sentences that are translated. Then, lastly stage is free translation. In this stage, it assumes linguistic structure is not important because the focus is on the meaning equivalency. In addition, Hornby (1995:2) said that ability is a mental or physical capacity, skill or strengthrequired to do anything. It means that ability can be assumed as a competence, capacity, capability, and mind power. Sometimes ability is also defined as cleverness or intellegence. So, ability is a natural capacity or talent who have by someone to get a successfully.

Based on the previously explanation, the conclusion that translation ability is a skill, competence, and intellegence in changing the language meaning of source language intothe equivalent of target language. It means that even though the form grammatical structure of sentences are changing,but the meaning of the source language should be equivalent.Therefore, ability to translate is one capacity to transfer ideas or thought from a language to another language, means that from source language to target or receptor language.

\subsection{Translation Types}

There are several types of translation method in translating a text. It is proposed by Newmark (2004:18). The types are as follows:
1. Word for word

Word for word translation is a type of translation that basically still very tied to the words level. In other words it is a simple type of translation that just translates the source language text into target language text directly without making changes to the order of source language to target language, for example, I go to school (Saya pergi ke sekolah).

\section{Literal Translation}

This type of translation might first be done like word for word translation, but then the translator makes changes the order or structure of the target language. For example, "The thief was sent to the prison"the meaning "Pencuri itu dipenjarakan(Literal)"

3. Loyal Translation

A loyal translation or faithful translation seeks to produce the right contextual meaning in the original text with the limitation of the grammatical structure of source language. In this translation, the vocabulary is transferred and lexical level is maintained, so that the translation is made to be truly faithful to the intent of the text of source language, this is also tends to as far as possible maintain or loyal to the content. For example, "Born without arms, he was sent to special schools" the meaning "Lahir tanpa lengan, dia dikirim ke sekolah khusus (harfiah)" or "Karena dilahirkan tanpa 
lengan, dia bersekolah di sekolah khusus (Bukan 'karena lahir...disekolahkan...')

\section{Semantic Translation}

This translation is different with loyal translation or faithful translation because semantic translation retains the aesthetic value of source language text and adjusts the meaning when the repetitions of words do not interfere in the translated version. In this translation, less important cultural words are not translated in cultural terms, but in functional culturally neutral terms.

\section{Adaptation}

This is the most free of translation form and it is mainly used in the translation of drama or plays (comedies) and poetry; the themes, characters, plot are usually retained, but the source language cultural is changed to the target language or receptor language cultural.

\section{Free Translation}

This type of translation produces the matter without the manner, or the contentwithout original form. This rather same as longer paraphrase than the original material which is also called intralingua translation', it is often wordy, excessive, and evensnot a translation at all.

\section{Idiomatic Translation}

This type produces the original message, but it tends to change the sense of meaning by preferring and using more colloquialisms and idioms in source language.

\section{Communicative Translation}

Communicative translation seeks to divert the exact contextual meaning of source language text in such a way that both the content and language are easily accepted and can be understood by the reader. Then, it can be understood by the reader.

Based on explanation above, there is one line of similarity that is translation process consists of three parts; word by word, literal, and free. Translation process above is useful to produce the precise understanding of meaning so that translation result has the similarity of message, impression, nuance, and context. Translation always begins from understanding word by word and followed by meaning of word in analyze of grammatical.

\subsection{Factors of Translation}

In translating a text, there are some influencing factors of translation. According to Rokhman (2008:11) in translating a text, there are factors that influence the translation process that include contextual, textual, and translator factor. This factor is related with the text production context that include language history, text writer, the culture text places is producted, the region text place is producted, text social variation, and topic of text. This element can be called contextual factor. Then, textual factor is formed by elements likes; word, phrase, clause, sentence, punctuation, and grammatical text. The last factor is 
translator. Translating process can not be separated from the element of translator itself. This condition is affected by some factors such as: competency of the translator, their perception, and the instrument which is used by them in translating process.

\subsection{Process of Translation}

In translating, it should be known the process of translation before starting to translate.Nababan (1999:24) states that Process of translation is an activity system in translation activity. It can be drawn as picture below:

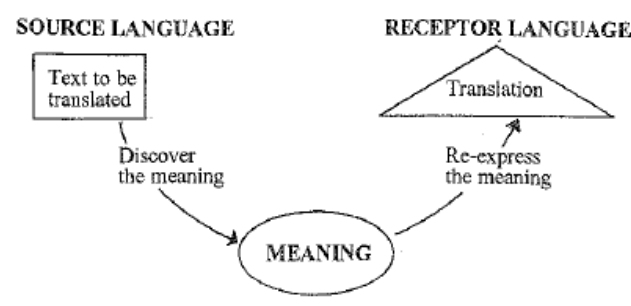

Figure 1. Process of Translation

He also divides translation process into three main steps as follows:

1. Analyzing the Source Language (SL)

To translate the source language into the target language, the translator has to read the whole text of source language by reading and understanding the content of message of the text in order to know what the writer or author wants to convey so that the authenticity of the source language message is still maintained or original when it is already translated into the target language.

2. Transferring the Message

The next step is transferring the message. In this transfer phase, the material of the source language that has been analyzed before has been analyzed and traced in the first stage transferred in the mind of the translator from the source language into the target language. At this stage this stage the work of the brain operates in order to find the originality and equivalency of some information understood on the first stage.

\section{Restructuring}

The last stage of translation is restructuring, it means that the translator rearranges the target language text based on the intent of the author of the source language text so that the result of the translation has an appropriate and good readability, style, and language rules or grammatical structure that are appropriate and acceptable within the target language. if there is an error or mistake of translation, the translator can check and revise by comparing and matching the content of message between those two languages.

According to Suryawinata in Nababan, 1999:25), there are three stages of translatingprocess which should be passed by the students. Firstly is analysis. In this stages, the student should analyze the text in the form of source language text. When they 
have understood, they should transfer the message text from source language text into target language text or receptor language. In this step, thestudents should translate it into English. If their mastery in simple present tense is high, probably they will be easy to translate the text. The last step is restructuring. In this step, the students should evaluate and revise what they have been done before. In this step, it can be said that the text that has been translated by them will be evaluated by the process which is called as rereading, and then, when this process has done, the students will know where the part of their translation that should be revised. All of the processes have proposed to increase their translation result. It means that, to get better translation result, the students should arrange the structure through the process of restructuring.

\subsection{Concept of Group Work}

According to Brown in Kasim (2015:99), group work is a teaching and learning process, which is a way of teaching where the students in a class is divided into groups of three to four students. Group work is also as group activities of students which are usually organized for giving the beneficial of teaching and learning process. The success of this work requires cooperative activities from various individuals.

While Richards, at.al in Kasim (2015:99) also said that group work as a learning activity to teach that has a goal in order the students are able to work, to overcome together their learning with other members in achieving the goal of learning. In addition, Harris and Sherblom in Kasim (2015:99) defines a group work is a learning strategy that tells students to work together in a group rather than explaining classically. The active learning strategy by group work can increase from the concept or principle of brain work theory, constructivist learning theory, and collaborative or cooperative learning. It can be concluded that group work emphasizes the activity and active participation of students from an intellectual and emotional perspective optimally through learning activities within the team to gain mastery or understanding the material in a more meaningful way. Group work, according to Johnson et.al in Kasim (2015:99),there are several elements of group work are as follows: (1) positive interdependence, it does not mean that students are depend on the other students. If the students rely on other students without share and discuss to each other, it cannot be called as positive dependence. It also creates good atmosphere that encourages students to feel need each other. This feeling of mutual need is called with positive interdependence that can achieve through the dependence of goals, assignment, or learning materials. (2) face to face interaction, it demands all members in the group can face each other, 
so they can communicate directly not only with the teacher, but also with their friends in their group. This is necessary because the students can be as source of learning for other students. (3) social skill, this element requires students to be equipped with various of social skills likes leadership, making decision, building trust, communication skill, and management skill, also other social skill such as tolerance, politeness, criticize ideas, and establishing interpersonal relationship.

It can be concluded that Group work can create interaction, communication contexts in which the students have interpersonal relationship. In addition, group work increases opportunities for students to comprehend the social situation in the classroom and to obtain modelling and feedback from their group.

\subsection{Advantages of Group Work}

Among the advantages of the group work, Brown in Kasim (2015:100) mentions these advantages of group work. The following advantages are:

1). Making students are active and creative in looking for the materials to complete their assignments.

2). Encouraging students to express verbally their ideas, and it can help them to understand the subject matter.

3) increasing students leadership and teaching discussion skill in group processes.
4) Involving students actively in learning and this can increase their achievement and retention.

5) Helping students learn to respect each other both high and low level of ability to work, share, and discuss together.

6) Providing opportunities for all students to contribute ideas and to complete their material or their task. In addition to the above advantages, Brumfit in Kasim (2015:101) mentions that group work provides a 'naturalistic environment'. This means that students in group work are free from anxiety to experiment with the target language. This is like when they are exposed to a certain linguistic environment in which they can pick up the language.Further, group work is arranged by the teacher with the aim to arouse the motivation of all students including low ability level students through good cooperation, mutual respect, and help as well as social interaction with each other. Jacob in Kasim (2015:101) also touches some advantages of group work in cooperative learning.

\subsection{Disadvantages of Group Work}

Beside theadvantages of group work, it also has disadvantages, according to Brown in Kasim (2015:101) mentions fourweaknesses of the applying of group work in teaching in the classroom, the first is group work is more time consuming, so it is not in line with the principle of efficiency. The second is it can cause the dependence 
on the group so that the students do not get involving in discussion activity because they only rely on their friends in their group. The third, it can lead to the dominance of group that has high ability performance so that the other groups (low ability) do not have opportunity or meaningful contribution, and the last it allows protracted decision making, if there is without good cooperation, the work team may not produce anything and allow for negative synergy.

\section{DISCUSSION}

Based on the previous theories above, the learning process done during open lesson relates with the title "Enhancing Students' Translation Ability Through Group Work", the lecturer did some stages during open lesson in teaching translation subject, the stages consist of Plan, Do, and See/Reflection, the stages can be explained as follows.

1. Plan

The stage of "Plan" was done in the pre-activity,in this stage the lecturer prepared the lesson plan of translation subject, media and materials in each cycles before learning process done in the class, the meeting done in 8 meetings.

2. Do

The next stage is "Do" (open lesson), this stage the lecturer as a model taught based on the plan of translation subject that she designed based on the goal of the learning in three activities, the first activity is pre-activity which consist of 10 minutes (aperception), this activity the lecturer greeted and checked the students attendance and the readiness of class. then in whilts activity which consist of 70 minutes, the lecturer delivered the material based on each meeting, and make sure all students have made a group which consist of 3 to 4 students and sometime the lecturer divided in pairs. The lecturer delivered the material that taught in 8 meetings. In several meetings, the lecturerdivided the students into some groups to discuss and share their translation result relate the task given before; after they are ready to perform their answer, one of members of each group gave their answer or result in front of the class to be discussed together with the lecturer and other groups, the discussion is not only done in the class, sometime the lecturer did it outdoor class at the other meetings, this is done to make their activity is not monotonous in the class, the lecturer asked to divide some group to present their performance relates with the material discussed. The activity is also done in group and in pairs, if the discussion done in pairs, it means that one student as speaker and the other one as translator, the speaker delivered the material in Indonesian and one as translator translated it into English, and vice verse. During their performance, the lecturer gave comment or suggestion if they did the 
mistake or inappropriate answer.The last activity is post activity which consist of 20 minutes, this activity lecturer concluded the material already discussed and inform to the students about the next material will be discussed in the next meeting.

3. See or Reflection

The last stage is "See/Reflection", this stage done after the open lesson is over, the lecturer reflected the teaching and learning process has already finished in each meeting. The purpose to be done it is to inform the strength and the weaknesses during learning process, it is hope that the weaknesses during learning process in the previous meeting will not be done anymore in the next meeting in order make the next teaching and learning to be better.

\section{CONCLUSION}

Based on the previous discussion, the writer concludes that by implementing group work technique, it gives many benefits for teaching and learning especially for teaching and learning translation subject, by implementing it the students became more active, motivated, and antusiastic during learning process, not only that their mastery in translation subject isincreased.

\section{REFERENCES}

Bell, Roger, T. (1991). Translation and Translating: Theory and Practice. London: Longman.

Febrina, Nila. Mukhaiyar and Zaim, M. (2013). Journal English Language Teaching (ELT). Vol. 1 No. 1, Page 1-20.

Hornby, A.S. (1974). Oxford Leaner's Dictionary of Current English. New York: Oxford University Press.

Kasim, Usman. (2015). Implementation of Group Work in the Classroom. Lingua, Vol. 12, No. 1, page 1-10.

Nababan, M. Rudolf. (1999). TeoriMenerjemahkan Bahasa Inggris. Jakarta: PustakaPelajar.

Newmark, Peter. (1988). A Textbook of Translation. New York: Prentice Hall International.

Rokhman, Arif. Teori dan Praktik Menerjemahkan Bahasa Inggris-Indonesia. Jakarta: Pustaka Pelajar.

Slavin E, Robert.(2005). Cooperative Learning: RisetdanPraktik. Bandung: Nusa Media. 